\title{
Differentiation-induced gene expression in 3T3-L1 preadipocytes: CCAAT/ enhancer binding protein interacts with and activates the promoters of two adipocyte-specific genes
}

\author{
Robert J. Christy, ${ }^{1}$ Vincent W. Yang, ${ }^{1,2}$ James M. Ntambi, ${ }^{1}$ Deborah E. Geiman, ${ }^{1}$ William $H$. \\ Landschulz, ${ }^{5}$ Alan D. Friedman, ${ }^{5}$ Yusaku Nakabeppu, ${ }^{3,4}$ Thomas J. Kelly, ${ }^{3}$ and M. Daniel Lane ${ }^{1}$ \\ ${ }^{1}$ Departments of Biological Chemistry, ${ }^{2}$ Medicine, ${ }^{3}$ Molecular Biology and Genetics, ${ }^{4}$ Howard Hughes Medical Institute \\ Laboratory, The Johns Hopkins University School of Medicine, Baltimore, Maryland 21205 USA; ${ }^{5}$ Howard Hughes Research \\ Laboratories, Department of Embryology, Carnegie Institution of Washington, Baltimore, Maryland 21209 USA
}

\begin{abstract}
Previous studies have shown that differentiation of 3T3-L1 preadipocytes leads to the transcriptional activation of a group of adipose-specific genes. As an approach to defining the mechanism responsible for activating the expression of these genes, we investigated the binding of nuclear factors to the promoters of two differentiation-induced genes, the 422(aP2) and stearoyl-CoA desaturase 1 (SCD1) genes. DNase I footprinting and gel retardation analysis identified two binding regions within the promoters of each gene that interact with nuclear factors present in differentiated 3T3-L1 adipocytes. One differentiation-induced nuclear factor interacts specifically with a single binding site in the promoter of each gene. Competition experiments showed that the interaction of this nuclear factor with the SCD1 promoter was prevented specifically by a synthetic oligonucleotide corresponding to the site footprinted in the 422(aP2) promoter. Several lines of evidence indicate that the differentiation-induced nuclear factor is CCAAT/enhancer binding protein (C/EBP), a DNA-binding protein first isolated from rat liver. Bacterially expressed recombinant C/EBP binds to the same site at which the differentiation-specific nuclear factor interacts within the promoter of each gene. Northern analysis with RNA from 3T3-L1 cells shows that C/EBP mRNA abundance increases markedly during differentiation. Transient cotransfection studies using a C/EBP expression vector demonstrate that C/EBP can function as a trans-activator of both the 422(aP2) and SCD1 gene promoters.
\end{abstract}

[Key Words: C/EBP; AP-1 (Jun)]

Received June 8, 1989; revised version accepted July 12, 1989.

The 3T3-Ll preadipocytes (Green and Kehinde 1974, $1975,1976)$ differentiate under appropriate stimuli into cells possessing the biochemical and morphological phenotype of adipocytes (Mackall et al. 1976; Coleman et al. 1978; Rosen et al. 1979; Reed and Lane 1980; Student et al. 1980). This differentiation is accompanied by a dramatic rise in the cellular levels of lipolytic and lipogenic enzymes, as well as other protein characteristic of adipocytes.

We (Bernlohr et al. 1984; Ntambi et al. 1988; Kaestner et al. 1989a,b) and others (Spiegelman et al. 1983; Chapman et al. 1984) isolated and analyzed several cDNAs whose genes are activated transcriptionally during adipocyte conversion (Bernlohr et al. 1985; Cook et al. 1985|. Differentiation of 3T3 preadipocytes leads to a 50- to 100-fold increase in the cellular levels of mRNA corresponding to these cDNAs and a coordinate rise in the levels of the proteins that they encode. One of these cDNAs encodes the adipocyte $422(\mathrm{aP} 2)$ protein, which has a high amino acid sequence identity to myelin P2 protein and certain other intracellular fatty-acid-binding proteins (Spiegelman et al. 1983; Bernlohr et al. 1984; Chapman et al. 1984; Matarese et al. 1988). Another cDNA, isolated from a 3T3-Ll adipocyte cDNA library (Bernlohr et al. 1984; Ntambi et al. 1988), encodes the message for stearoyl-CoA desaturase 1 (SCD1), a key enzyme for monounsaturated fatty acid synthesis that is expressed differentially during 3T3-L1 adipocyte conversion (Enoch et al. 1976; Ntambi et al. 1988).

The $422(\mathrm{aP} 2)$ and SCD1 genes have been cloned and their $5^{\prime}$-flanking sequences characterized (Hunt et al. 1986; Phillips et al. 1986; Cook et al. 1988; Ntambi et al. 1988). Transfection experiments with chimeric 422(aP2) promoter-CAT constructs show that the gene is activated by glucocorticoid and cAMP (Cook et al. 1988; Yang et al. 1989), two agents used to induce differentiation of 3T3-Ll preadipocytes. It has been demonstrated that the first $168 \mathrm{bp}$ of the $5^{\prime}$-flanking sequence of this 
gene are sufficient for differentiation-dependent expression in 3T3-442A preadipocytes (Distel et al. 1987). Within this sequence, a 28-bp region, denoted FSE2 (Distel et al. 1987), was identified and shown to interact with a Fos-like protein in nuclear extracts from 3T3-442A adipocytes. This region contains a consensus AP-1 (Jun\}-binding sequence with which a complex of two proto-oncogenes, (i.e., c-fos and c-iun or their related gene products), interact (Distel et al. 1987; Rauscher et al. 1988; Franza et al. 1988; Nakabeppu et al. 1988; Cohen et al. 1989|. A DNA-protein interaction in the region of the AP-1 (Jun) site appears to inhibit expression of the $422(\mathrm{aP} 2)$ gene in $3 \mathrm{~T} 3$ preadipocytes (Distel et al. 1987; Yang et al. 1989). Transfection experiments with chimeric SCDl promoter-CAT constructs in 3T3-L1 preadipocytes have shown that 363 bp of the SCDI 5'-flanking region contain sequences that promote CAT expression; this expression is activated by cAMP, one of the agents known to induce differentiation of 3T3-Ll preadipocytes (Ntambi et al. 1988).

The CCAAT/enhancer binding protein $(\mathrm{C} / \mathrm{EBP})$ is a sequence-specific, heat-stable, DNA-binding protein that was purified first from rat liver nuclei /Graves et al. 1986; Johnson et al. 1987). This protein binds to CCAAT boxes of the murine sarcoma virus long terminal repeat
(MSV LTR), the herpes simplex virus thymidine kinase (HSVtk) promoter (Graves et al. 1986; Johnson et al. 1987), and the enhancer regions of SV40, MSV, polyoma virus (Johnson et al. 1987), hepatitis B virus (Landschulz et al. 1989), and several avian retroviral LTRs (Ryden and Beemon 1989|. Recently, the tissue distribution of C/EBP mRNA was investigated, and high levels of expression were detected in liver, as well as adipose and other lipogenic tissues (Birkenmeier et al. 1989). It was demonstrated (Birkenmeier et al. 1989) that C/EBP message and protein levels increase during differentiation of 3T3-422A and 3T3-Ll cells, respectively.

In the present investigation, we sought to identify binding sites in the $5^{\prime}$-flanking regions of the 422(aP2) and SCDl genes that are involved in the coordinate differentiation-induced expression of these genes in 3T3-L1 preadipocytes. Two specific nuclear-factor-binding sites were identified in the promoters of each gene. Specific binding of nuclear factors in 3T3-L1 cells was demonstrated at the AP-1 (Jun) consensus sequence of the $422|\mathrm{aP} 2|$ gene and at a unique site within the SCD1 gene. We found also that the 5 '-flanking regions of both the 422(aP2) and SCDl genes bind another nuclear factor $\mathrm{C} / \mathrm{EBP}$, which is expressed at a markedly increased level upon differentiation of $3 \mathrm{~T} 3-\mathrm{L} 1$ preadipocytes. Cotrans-
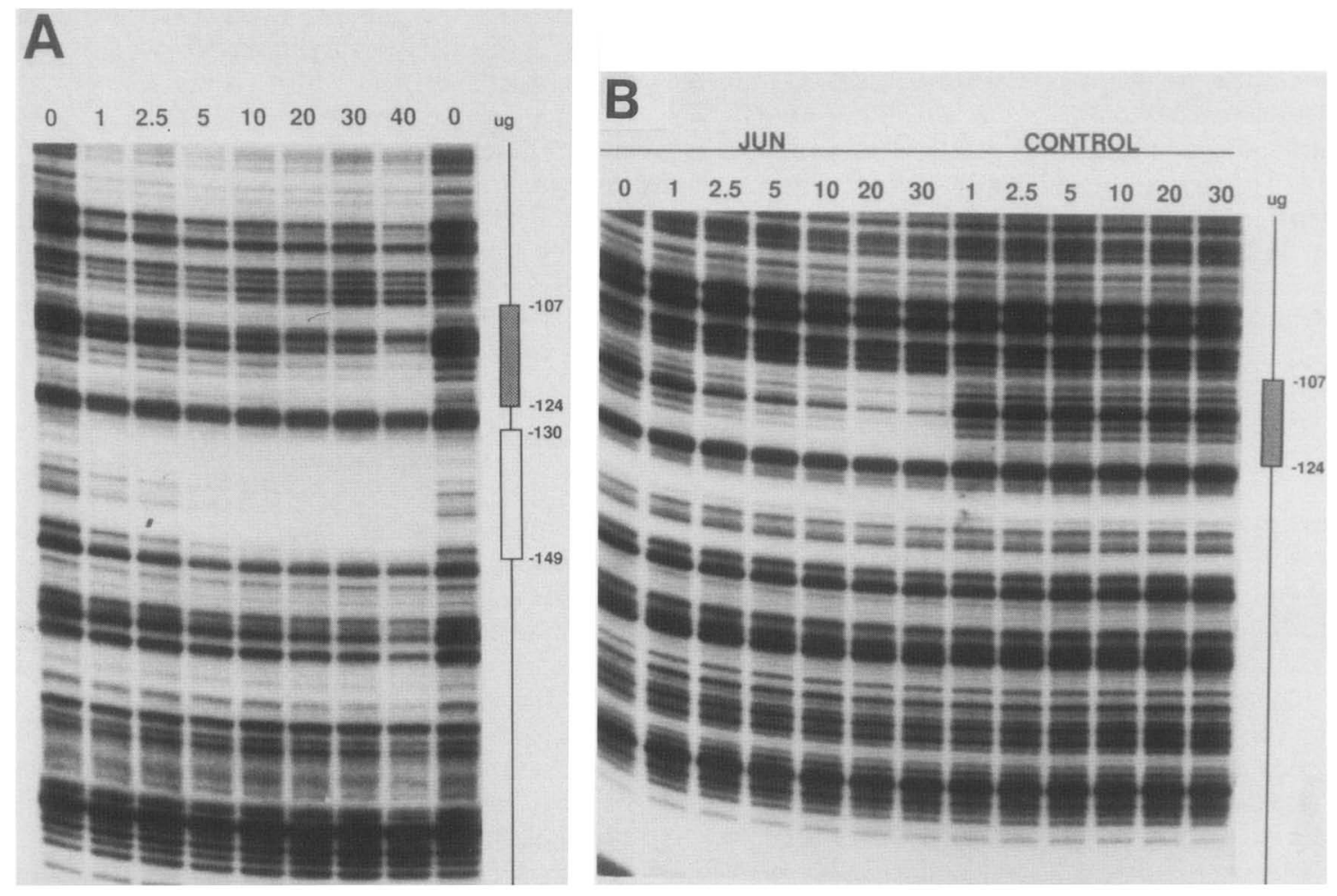

Figure 1. DNase I footprint analysis of the promoter of the $422(\mathrm{aP} 2 \mid$ gene. The coding strand of the 248 -bp NsiI-PstI fragment from the promoter of the $422(\mathrm{aP} 2)$ gene was subjected to DNase I footprinting. $(A)$ Increasing amounts $(1-40 \mu \mathrm{g})$ of nuclear extracts from differentiated (day 4) 3T3-Ll cells were incubated with the 248 -bp promoter fragment and digested with DNase I. The protected regions are boxed; the end points $(-124$ to -107 and -149 to -130$)$ were identified by chemical sequencing (Maxam and Gilbert 1980). (0) Contol reaction with no protein added. (B) Increasing amounts (1-30 $\mu \mathrm{g}$ ) of bacterially expressed recombinant c-jun or control bacterial extract (lacking c-jun) was incubated with the 248-bp fragment and digested with DNase I. The region protected $(-124$ to -107$)$ by bacterially expressed c-jun, which contains an AP-1 (Jun) consensus binding site, is boxed and its end points are indicated. (0) A control footprint with no bacterial extract added. 
fection of $422(\mathrm{aP2})-$ or SCD1-promoter-CAT constructs with a C/EBP expression vector in 3T3-L1 preadipocytes showed that C/EBP trans-activates both the $422(\mathrm{aP} 2)$ and SCD1 gene promoters, thus implicating $\mathrm{C} / \mathrm{EBP}$ in differentiation-specific gene expression.

\section{Results}

DNase I footprinting of the 422(aP2) and SCD1 promoters by nuclear extracts from differentiated 3T3-L1 adipocytes

Nuclear extracts from differentiated 3T3-L1 adipocytes were analyzed to identify trans-acting factors that bind to the $5^{\prime}$-flanking sequences of the $422(\mathrm{aP} 2)$ and SCD1 genes. The coding strand of the 248-bp NsiI-PstI fragment (Cook et al. 1988) of the 422(aP2) promoter was subjected to DNase I footprinting. Figure 1A shows that two regions, between nucleotides -147 and -128 and between nucleotides -124 and -107 , are protected from DNase I digestion by the nuclear extract. Previous studies (Distel et al. 1987) showed that a nuclear factor, present only in differentiated 3T3-442A adipocytes, binds between nucleotides -124 and -107 (designated FSE2) of the 422(aP2) promoter. This region contains the consensus AP-1 (Jun)-binding site sequence, TGACTCA (Rauscher et al. 1988). To characterize binding at the AP-1 (Jun) site, DNase I footprinting experiments were performed using the 248-bp 5'-flanking sequence of the $422(\mathrm{aP} 2)$ gene and bacterially expressed recombinant c-Jun protein. Figure 1B shows that the region between nucleotides -124 and -107 is protected by c-Jun and gives the same digestion pattern as with nuclear extracts from 3T3-Ll cells.

Nuclear extracts from differentiated 3T3-L1 adipocytes also give rise to another site of DNase I footprint protection (nucleotide -149 to -130 ) just upstream of the AP-1 (Jun) consensus binding site (Fig. lA). This region contains the sequence CAAAGTTGAGAAATTTCTATT, which includes a 10-bp palindrome (underlined). Deletion analysis has shown that this specific region is important in the activation of the $422(\mathrm{aP} 2)$ promoter in 3T3-442A adipocytes (Distel et al. 1987).

The $5^{\prime}$-flanking region of the SCDI gene also was subjected to DNase I footprinting with nuclear extracts from 3T3-Ll adipocytes (Fig. 2). The 120-bp BstNI fragment (nucleotides -136 to -13 ; see Ntambi et al. 1988) was prepared and footprinted. Two regions, from nucleotide -114 to -86 and from nucleotide -80 to -56 , were protected from DNase I digestion by factors in the nuclear extract. The sequence of one of these regions (CTGCGCTCTTTACCCTTTGCTGGCAGCCG), between nucleotide -114 and -86 , contains an imperfect direct repeat (underlined). This region also has no sequence homology to the consensus binding sites of any other transcription regulatory proteins (Wingender 1988). The binding protein that interacts at this site is designated SCD1/BP. The other footprinted region, which is located between nucleotides -80 and -56 , is specific for nuclear extracts from differentiated cells and

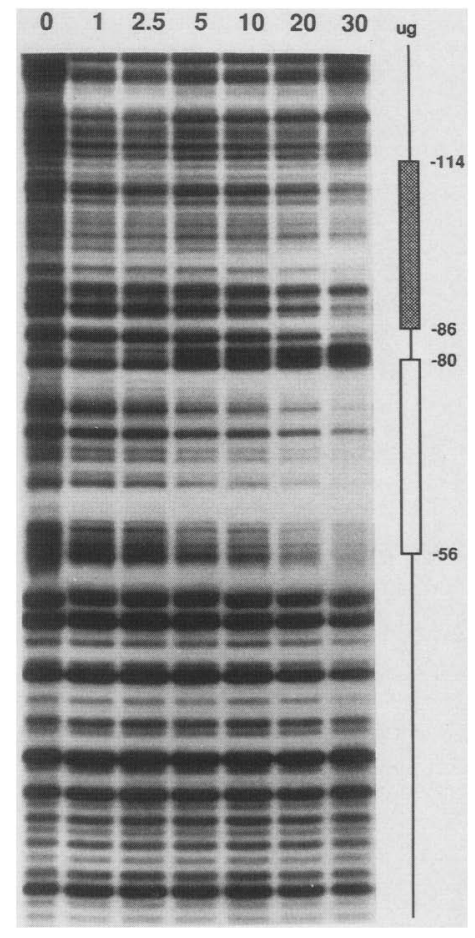

Figure 2. DNase I footprint analysis of the promoter of the SCD1 gene. The 120-bp BstNI fragment of the SCD1 promoter was incubated with increasing amounts $(1-30 \mu \mathrm{g})$ of nuclear extracts from differentiated (day 4) 3T3-L1 cells and digested with DNase I. The protected regions are boxed; and the end points $(-80$ to -56 and -114 to -86$)$ were identified by chemical sequencing (Maxam and Gilbert 1980). (0) A control footprint with no nuclear extract added.

has been shown by deletion mutation analysis to be essential for expression of chimeric SCD1 promoter-CAT constructs in 3T3-L1 cells (J.M. Ntambi and M.D. Lane, unpubl.).

Changes in the binding of nuclear factors to the 422(aP2) and SCD1 promoters during differentiation

Nuclear extracts from differentiated and undifferentiated 3T3-Ll cells were used to footprint the promoters of the $422(\mathrm{aP} 2)$ and SCD1 genes. Footprints of the $422(\mathrm{aP} 2)$ promoter are shown in Figure 3A. Nuclear extracts from cells induced to differentiate for 2,4 , or 6 days completely protected the region from nucleotide -149 to -130 . Protection in this region did not occur, however, with nuclear extracts from undifferentiated cells, totaling $40 \mu \mathrm{g}$ of undifferentiated nuclear extract (results not shown). Binding to the AP-1 (Jun) consensus sequence is not detected using nuclear extracts from either undifferentiated or differentiated 3T3-L1 cells at the lower level of nuclear extract needed to footprint the region between nucleotides -149 and -130 . Equivalent footprinting at the AP-1 (Jun) site is observed with nuclear extracts from undifferentiated (data not shown) or differentiated 3T3-L1 cells (Fig. 1A). 


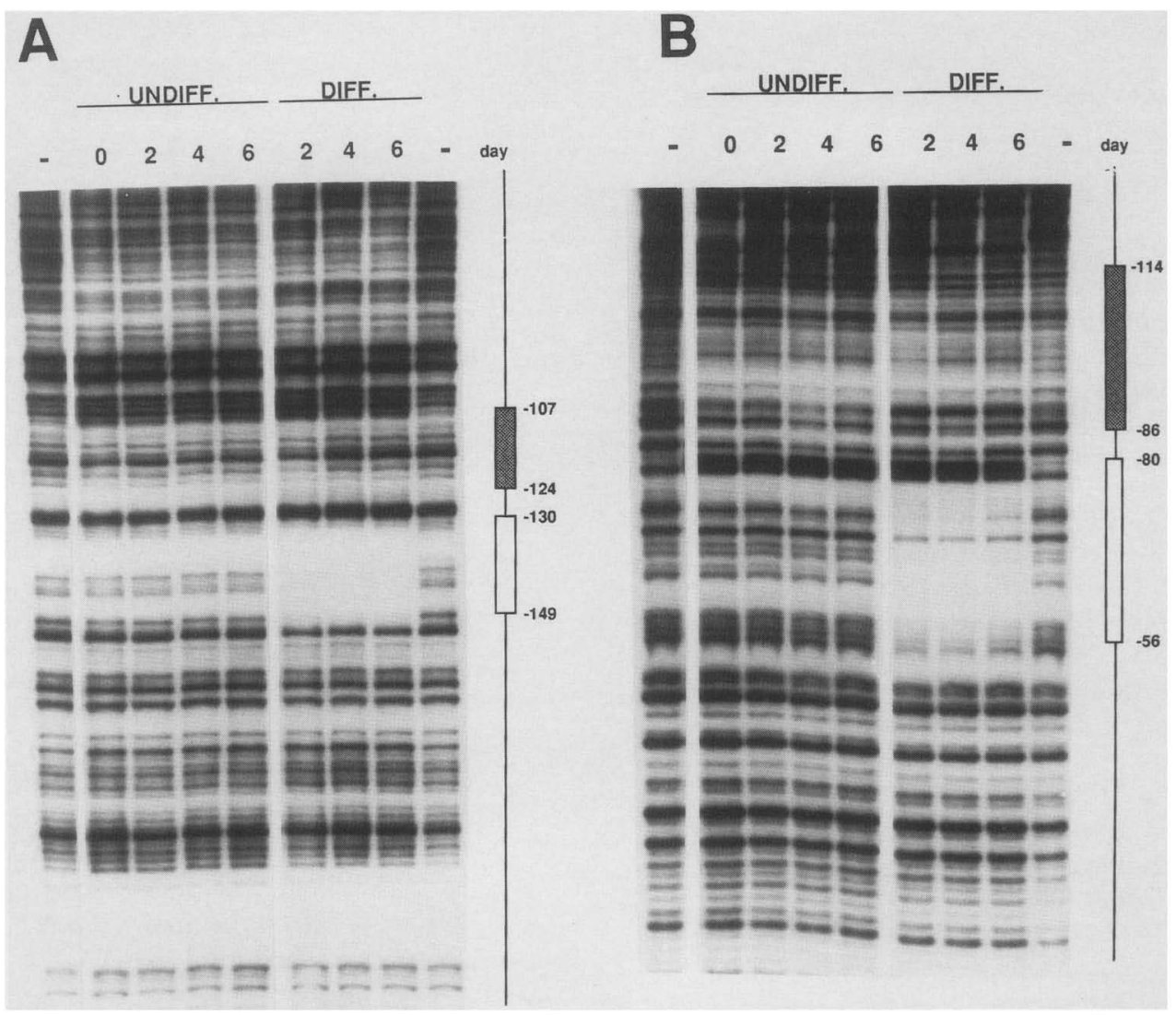

Figure 3. DNase I footprint analysis of the $422(\mathrm{aP} 2)$ and SCD1 promoters with nuclear extracts of $3 \mathrm{~T} 3-\mathrm{L} 1$ cells at different stages of differentiation. 3T3-Ll preadipocytes were cultured to 2 days postconfluence (day 0 ) and were either maintained in the undifferentiated state (UNDIFF.) or induced to differentiate (DIFF.) (see Materials and methods). Nuclear extracts were prepared from 3T3-L1 preadipocytes (UNDIFF.) or 3T3-Ll cells that were induced to differentiate (DIFF.) on days 2, 4, and 6. Five micrograms of each nuclear extract was incubated with the 248-bp NsiI-PstI coding strand of the 422 (aP2) promoter $(A)$ or the 120 -bp Bst NI noncoding strand of the SCDI promoter $(B)$ and was then subjected to DNase I treatment. The regions protected by nuclear extracts from differentiated cells- $(A)-149$ to -130 and $(B)-80$ to -56 -are shown with open boxes, and end points are indicated. The shaded boxes indicate the regions protected in each promoter by larger amounts $(20 \mu \mathrm{g})$ of nuclear extract from both undifferentiated and differentiated cells (Figs. $1 \mathrm{~A}$ and 2 ) not detected by the lower amount $(5 \mu \mathrm{g})$ of nuclear extracts used in this experiment. $(-)$ Control footprints without addition of nuclear extract.

Nuclear extracts also were used to footprint the 120bp BstNI promoter fragment from the SCDl gene (Fig. $3 \mathrm{~B} \mid$. The region between nucleotides -80 and -56 of the SCD1 gene is protected completely from DNase I digestion by nuclear extracts from differentiated, but not by extracts from undifferentiated 3T3-L1 cells. Binding to the $\mathrm{SCD} 1 / \mathrm{BP}$ site is not detected at the concentration of nuclear extract needed to footprint the region between nucleotides -80 and -56 (see Fig. 2).

Comparison of the $422(\mathrm{aP} 2)$ and SCD1 promoter sequences that bind this differentiation-specific protein reveals that they do not contain a large region of nucleotide sequence homology, except for a 5-bp sequence GAAAT, that is found in both genes and makes up part of the 10-bp palindromic sequence in the $422(\mathrm{aP} 2)$ gene.

\section{Binding of the differentiation-specific nuclear factor to both the 422(aP2) and SCD1 promoters}

To determine whether the same differentiation-specific nuclear binding factor interacts with the promoters of both the 422(aP2) and SCD1 genes, competition gel retardation assays were performed. The 120-bp Bst NI fragment of the SCD1 promoter was end-labeled and incubated with nuclear extracts from differentiated 3T3-L1 cells in the presence or absence of various synthetic oligonucleotides as potential competitors. The amount of nuclear extract was titrated to the concentration at which only individual complexes are observed. Two sequence-specific oligonucleotide-nuclear protein complexes (Fig. 4, NE) were detected. The unlabeled 120-bp $B s t$ NI SCD1 promoter fragment blocks all complex formation (Fig. 4, BstNI). A synthetic oligonucleotide corresponding to nucleotides -80 to -59 within the SCD1 promoter at which the differentiation-specific nuclear factor binds, prevents formation of the low- molecularweight complex [Fig. 4, SCD1(-80 to -59$)]$. This suggests that the low-molecular-weight complex results from binding the differentiation-specific factor. Addition of the oligonucleotide corresponding to nucleotides -150 to -125 of the $422(\mathrm{aP2}$ ) promoter [Fig. 4, $422(-150$ to -125$)]$ also prevents the formation of the 


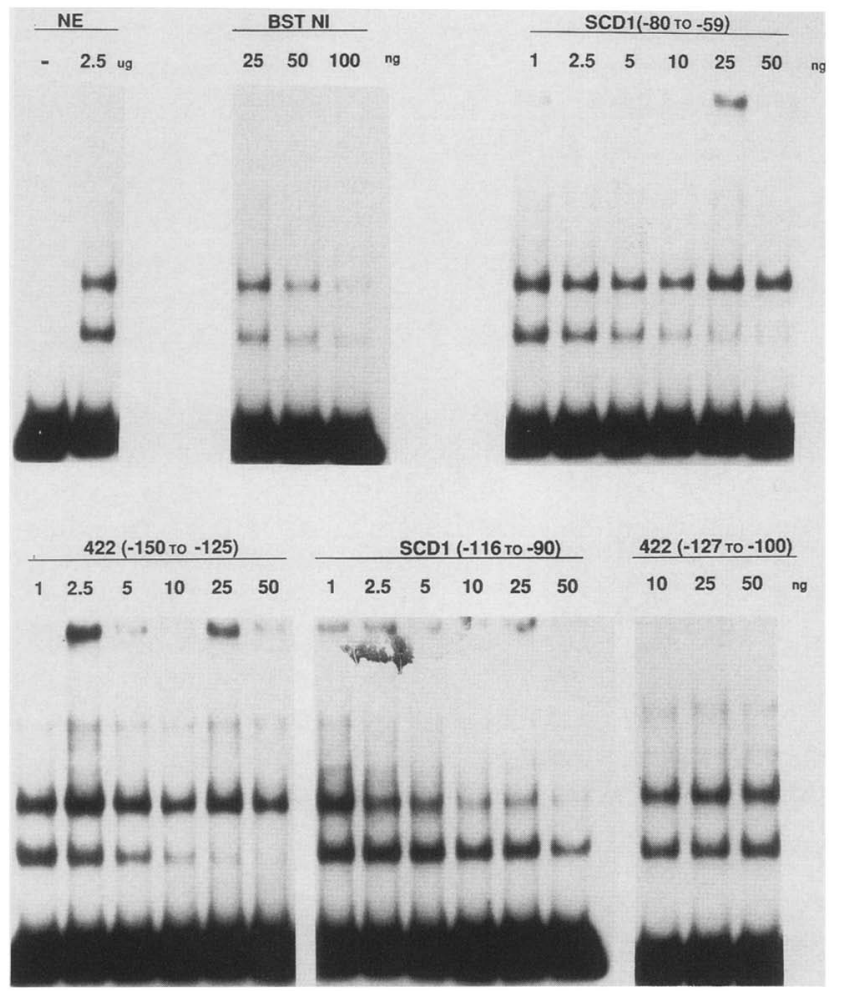

Figure 4. Gel retardation analysis of the nucleotide sequence specificity of nuclear factors from differentiated 3T3-L1 cell with the SCD1 promoter. (NE) ${ }^{32}$ P-labeled 120-bp BstNI fragment of the SCD1 promoter incubated with $(2.5 \mu \mathrm{g})$ or without $(-\mid 2.5 \mu \mathrm{g}$ of nuclear extract from differentiated 3T3-L1 (day 4) cells. The same amount of nuclear extract and ${ }^{32}$ P-labeled 120 bp BstNI fragment also was incubated with increasing amounts of various unlabeled DNAs or synthetic oligonucleotide competitors. The unlabeled synthetic oligonucleotides corresponds to the regions of specific interaction of nuclear factor from differentiated 3T3-L1 cells with the SCD1 and 422/aP2) promoters identified by DNase I footprinting (Figs. 1A and 2). (BstNI) The unlabeled 120-bp Bst NI fragment of the SCD1 promoter. [SCD1 $\{-80$ to $-59 \mid\}$ The $\mathrm{SCDl}$ differentiation-specific region; $[422(\mathrm{aP} 2)(-150$ to -125$)]$ the differentiation-specific region site in the 422(aP2) promoter; [SCDI $(-116$ to -90$)$ ] the SCDl/ $\mathrm{BP}$ region; [FSE2/ -127 to -100 )] the AP-1 (Jun) consensus binding site in the $422(\mathrm{aP} 2)$ promoter. The specific nucleotide sequences of the competitor oligonucleotides are given in Materials and methods and correspond to sequences shown in Fig. 7.

low-molecular-weight complex. Thus, the same nuclear factor associated with this complex binds with similar affinity to the differentiation-specific elements of both promoters.

The high-molecular-weight complex results from an interaction of the SCD1-specific binding factor /designated SCD1/BP) with the region between nucleotides -116 and -90 of the SCD1 promoter because formation of the complex is prevented preferentially by a synthetic oligonucleotide that corresponds to the sequence in this region [Fig. 4, SCDI $(-116$ to -90$)$ ]. The formation of both complexes is specific because an oligonucleotide, which encompasses the AP-1 consensus se- quence [Fig. 4, 422(-127 to - 100); (FSE2; Distel et al. 1987)] in the 422(aP2) gene and is not present in the SCD1 promoter, does not inhibit the formation of either complex.

Thus, the promoters of both the differentially expressed 422(aP2) and SCD1 genes form complexes with the same differentiation-specific nuclear factor that is present only in differentiated 3T3-L1 adipocytes. In addition, each promoter also binds at least one other unique nuclear protein/s): one at the AP-1 (Jun) site in the 422(aP2) gene (Fig. 1; Distel et al. 1987), and another (SCD1/BP) between nucleotides -114 and -86 in the SCDl gene.

\section{Identification of the differentiation-specific nuclear factor as $C / E B P$}

Investigation of the tissue distribution of C/EBP, a nuclear binding protein detected initially in rat liver (Graves et al. 1986; Johnson et al. 1987), revealed that this factor also is expressed at high levels in adipose tissue (Birkenmeier et al. 1989). Preliminary experiments indicated that C/EBP mRNA is present in 3T3-L1 adipocytes (results not shown). To determine whether expression of C/EBP mRNA increases during differentiation of 3T3-L1 preadipocytes, RNA was isolated during the course of differentiation and subjected to Northern analysis using a C/EBP cDNA probe. As shown in Figure 5 , expression of the C/EBP mRNA, $\sim 2.7 \mathrm{~kb}$, (Landschulz et al. 1988b; Birkenmeier et al. 1989) is induced by differentiation, exhibiting a dramatic rise in message abundance on day 2 following the induction of differentiation. The pattern of expression of the C/EBP gene mimics that of the 422(aP2) (Fig. 5; Bernlohr et al. 1985) and SCD1 (Bernlohr et al. 1985) genes.

To determine whether the differentiation-specific nuclear factor that binds to the $422(\mathrm{aP2})$ and SCD1

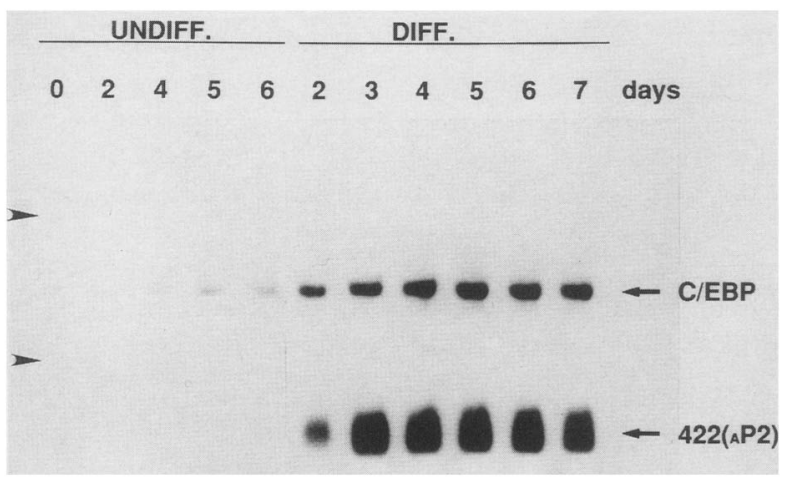

Figure 5. Differential expression of C/EBP mRNA during differentiation of 3T3-Ll preadipocytes. The 3T3-Ll preadipocytes were cultured to 2 days postconfluence (day 0 ) and were then either maintained in the undifferentiated state (UNDIFF.) or induced to differentiate (DIFF.) (see Materials and methods). Total RNA was prepared on the days indicated. Fifteen micrograms of RNA was subjected to electrophoresis on formaldehydeagarose gels; Northern blots were prepared and hybridized simultaneously with ${ }^{32} \mathrm{P}$-radiolabeled cDNA probes specific for $\mathrm{C} / \mathrm{EBP}$ and $422(\mathrm{aP2})$. Markers for $28 \mathrm{~S}$ and $18 \mathrm{~S}$ rRNA are indicated by arrowheads. 
5 '-flanking sequences is heat stable, like C/EBP (Landschulz et al. 1989), nuclear extract from differentiated 3T3-LI adipocytes was heat-treated at $70^{\circ} \mathrm{C}$ for $5 \mathrm{~min}$ and then subjected to DNase I footprinting. Figure 6A shows that heat-treated nuclear extract still footprints the $422(\mathrm{aP} 2)$ promoter between nucleotides -149 and -130 , the site at which the differentiation-specific nuclear factor binds. This heat-treated nuclear extract also footprints between nucleotides -80 and -59 of the SCD1 promoter (results not shown).

To determine whether the 422(aP2) and SCD1 promoters contain a C/EBP-binding site, the 422(aP2) and SCD1 gene promoters were footprinted using the bacterially expressed C/EBP recombinant protein /Landschulz et al. $1988 \mathrm{~b}$ ). Figure $6 \mathrm{~B}$ shows that recombinant C/EBP footprints the $422(\mathrm{aP} 2)$ promoter at the same site as the differentiation-specific factor (Figs. $1 \mathrm{~A}$ and $6 \mathrm{~A}$ ). Analysis of the SCDl promoter (Fig. 6C) demonstrated that bacterially expressed C/EBP also generates a footprint indistinguishable from that of the differentiation-specific factor (Fig. 2). These results, taken together with those described above, indicate that the differentiation-specific factor is C/EBP. Moreover, the sites at which C/EBP (and nuclear extracts from differentiated 3T3-L1 adipocytes) interacts with the $422(\mathrm{aP} 2)$ and SCD1 promoters are within the regions that have been shown to be essential for the activation of both genes during preadipocyte differentiation (Distel et al. 1987; Ntambi et al. 1988; Yang et al. 1989).

\section{Activation of the 422(aP2) and SCD1 promoters by $C / E B P$}

Transfection experiments with chimeric promoterCAT constructs of the 422(aP2) (Cook et al. 1988; Yang et al. 1989) and SCD1 (Ntambi et al. 1988) genes, which contain the C/EBP-binding site, are expressed during differentiation of 3T3-L1 preadipocytes. To determine whether C/EBP can activate expression driven by the promoters of these genes, $422(\mathrm{aP} 2)$ promoter-CAT and SCD1 promoter-CAT genes were cotransfected with pMSV-C/EBP-wt, an expression vector containing the rat C/EBP cDNA linked to the MSV LTR (Friedman et al. 1989).

The $422(\mathrm{aP} 2)$ promoter region (nucleotides -248 to $+20)$, without $(\Delta-248$.CAT) or with (ALS-122)143.CAT) a BamHI linker replacing the C/EBP-binding site (Fig. 7A), was inserted into a pBLCAT3' vector (Yang et al. 1989). The vector pBLCAT3', the wild-type promoter $\Delta-248$.CAT, or the mutant promoter $\Delta \mathrm{LS}-122$ / - 143.CAT, was cotransfected with either carrier DNA or the pMSV-C/EBP-wt expression vector. The results illustrated in Figure 8, which are expressed quantitatively in Table 1, show that the C/EBP expression vector markedly activates CAT expression when cotransfected with the $\Delta-248$.CAT construct but not when cotransfected with the $\Delta \mathrm{LS}-122 /-143$.CAT mutant lacking the C/EBP-binding site. Trans-activation of the 422(aP2) promoter by $\mathrm{C} / \mathrm{EBP}$ in this and other experiments ranged from 15- to $\sim 60$-fold. Moreover, cotransfection with
C/EBP expression vectors that encode defective mutant C/EBPs, that is, pMSV-C/EBP-BR3 and pMSV-C/ EBP-12V, which has amino acid substitutions at four positions in the highly basic region thought to be the region of DNA interaction, and pMSV-C/EBP-12V, in which leucines 317 and 324 are mutated to valines in the leucine zipper region, respectively (Friedman et al. 1989; Landschulz et al. 1989|, does not lead to trans-activation of the wild-type $\Delta-248$.CAT gene (results not shown). DNase I footprinting of the wild-type $\Delta-248$.CAT (Fig. 9A; see also Figs. 1, 3, and 6) and the $\Delta$ LS - 122/-143.CAT (Fig. 9B) promoters verifies that the $\Delta \mathrm{LS}-122 /-143$ mutant lacks the ability to bind bacterially expressed recombinant C/EBP or the adipocyte-specific nuclear factor from differentiated 3T3-L1 cells. The $\Delta$ LS - 122/-143 mutant which still possesses the AP-1 (Jun) consensus binding site retains the capacity to bind c-jun in differentiated nuclear extracts having an identical footprinting pattern that covers both the AP-1 (Jun) site and the BamHI linker sequence as it does with bacterially expressed recombinant c-Jun (Fig. 9C).

Similar experiments were conducted in which wildtype and mutant SCD1 promoter-CAT constructs (Fig. 7B) were cotransfected into 3T3-L1 cells, with or without the pMSV-C/EBP-wt expression vector. As shown in Table 1 , cotransfection of the $\Delta-93 . S C D 1 . C A T$ construct /containing the C/EBPbinding site) with pMSV-C/EBP-wt caused a 20 -fold activation of CAT expression. However, cotransfection of pMSV-C/EBP-wt with either the pBL-CAT3 vector or the $\Delta-58$.SCDI.CAT gene (lacking the C/EBP-binding site) caused only a threefold activation of CAT expression (Table 1). Thus, it is evident that C/EBP also can trans-activate the SCDl promoter.

These cotransfection experiments do not enable us to determine the level of C/EBP expression in each transfected cell. Therefore, although the transfections do not indicate the exact mechanism of C/EBP under normal physiological levels, the fact that C/EBP or certain agents used to induce differentiation of 3T3-L1 preadipocytes (Cook et al. 1988; J.M. Ntambi and M.D. Lane, unpubl.) can activate the $422(\mathrm{aP} 2)$ and SCD1 promoters suggests that C/EBP may play an important role in controlling gene expression during preadipocyte differentiation.

\section{Discussion}

Previous studies in this laboratory (Bernlohr et al. 1985) have shown that during differentiation of 3T3-L1 preadipocytes, the transcription of two adipose-specific genes [the $422(\mathrm{aP} 2)$ and SCD1] is activated coordinately. We now report that the promoters of each of these genes contain two binding sites with which nuclear factors interact specifically. One binding site within each promoter interacts with a nuclear factor, unique for that gene, which is expressed in 3T3-Ll cells. Each promoter possesses another binding site [between nucleotides -149 and -130 in the $422(\mathrm{aP} 2)$ promoter and between nucleotides -80 and -56 within the SCD1 promoter] at 


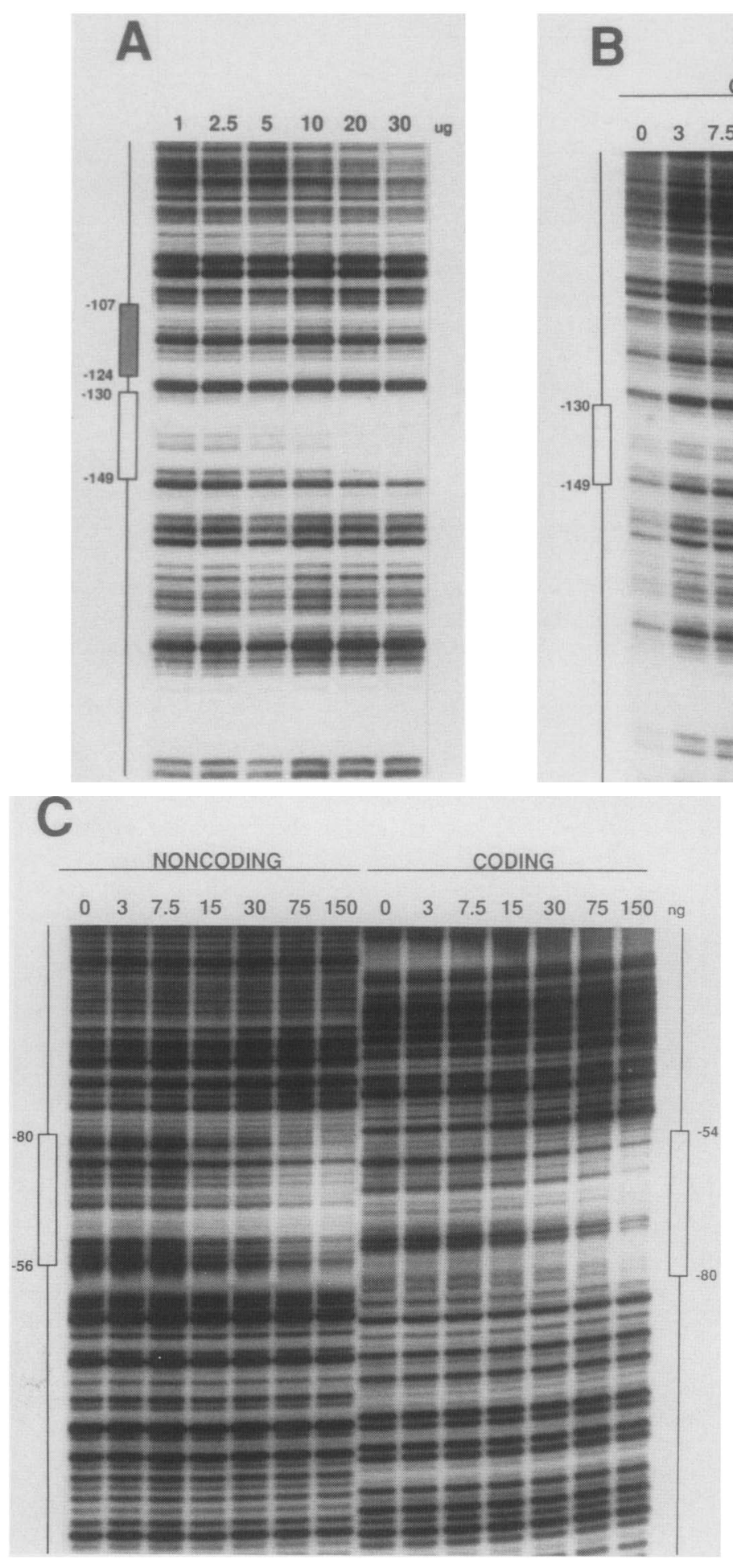

Figure 6. DNase I footprint analysis with heat-treated 3T3-L1 nuclear extract and bacterially expressed recombinant C/EBP. (A) Nuclear extract from differentiated 3T3-Ll (day 4) cells was heated to $70^{\circ} \mathrm{C}$ for $5 \mathrm{~min}$, after which the precipitated protein was removed by centrifugation and the supernatant used for DNase I footprint analysis. The 248-bp NsiI-PstI coding strand of the 422(aP2) promoter was incubated with increasing amounts (1-30 $\mu \mathrm{g}$ ) of the heat-treated nuclear extract and then digested with DNase I. The open box (nucleotides -149 to -130 ) indicates the differentiation-specific region still protected after heat treatment, the shaded box indicates the region of the AP-1 (Jun) consensus binding site /nucleotides -124 to - 107) within the 422(aP2) promoter (see Fig. 1). Purified recombinant C/EBP (3-150 ng; Landschulz et al. 1989) was incubated with the coding and noncoding strands of the 248-bp NsiI-PstI fragment of the $422(\mathrm{aP} 2)$ promoter $(B)$ or the 120-bp BstNI fragment of the SCD1 promoter $(C)$. The protected regions are boxed, and nucleotide end points of the C/EBP-binding site are indicated. $(0)$ Control reactions to which neither nuclear extract or recombinant C/EBP were added.

which the same nuclear factor, identified as C/EBP, interacts. Consistent with the tissue distribution of $\mathrm{C} / \mathrm{EBP}$, which is found in tissues with extremely active fatty acid metabolism (e.g., liver and adipose) (Birkenmeier et al. 1989), C/EBP mRNA is expressed at high levels in 3T3-Ll adipocytes but not in 3T3-L1 preadipocytes (Fig. 5; Birkenmeier et al. 1989).
The present study and that of Birkenmeier et al. (1989) provide evidence that $\mathrm{C} / \mathrm{EBP}$ is involved in differentiation-induced gene expression in 3T3 preadipocytes. Northern analysis shows that cellular C/EBP mRNA levels increase dramatically during differentiation of both 3T3-Ll (Fig. 5) and 3T3-442A preadipocytes (Birkenmeier et al. 1989). Moreover, the time-course of ex- 
Christy et al.

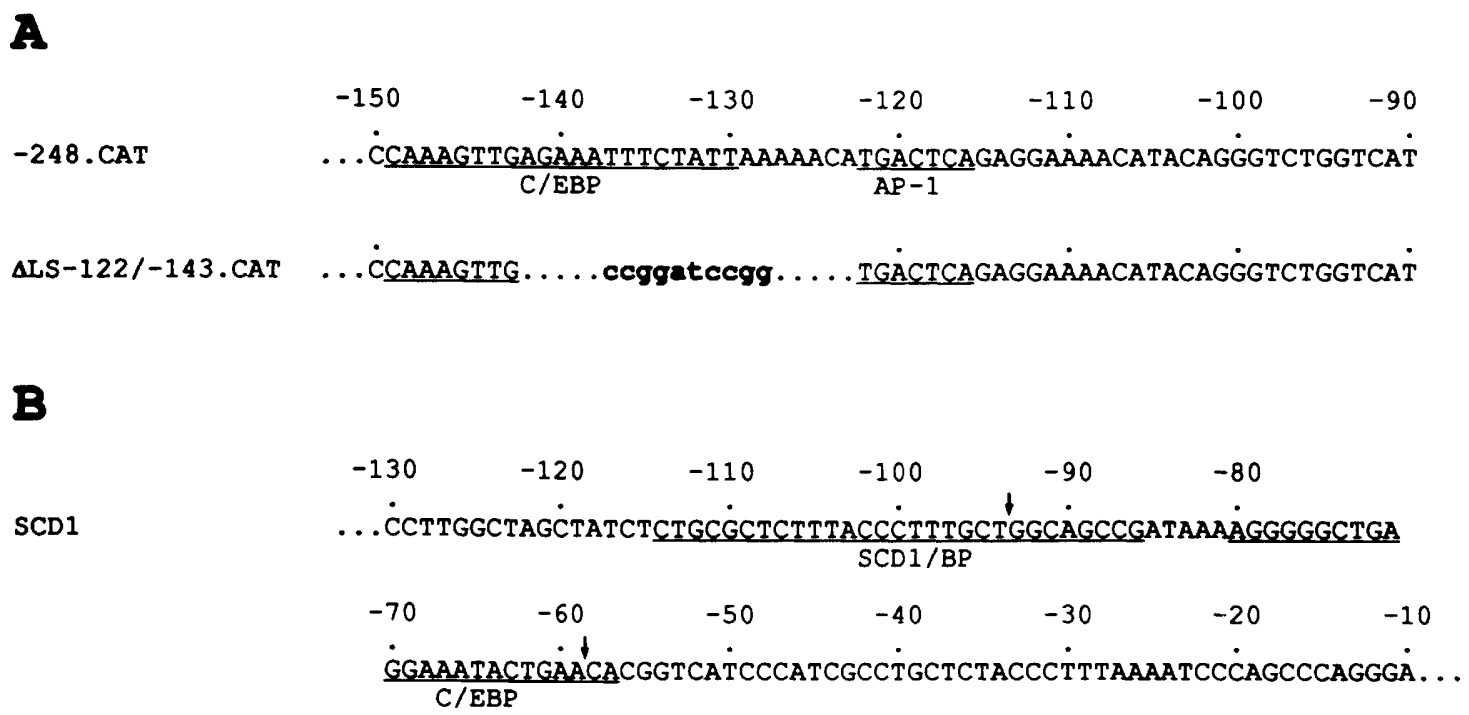

Figure 7. Nucleotide sequences of the $5^{\prime}$-flanking regions of the $422(\mathrm{aP} 2)(A)$ and stearoyl-CoA desaturase $(\mathrm{SCD} 1)(B)$ genes. $(A)$ Nucleotide sequences between positions -150 and -90 of the 422 (aP2) gene (Cook et al. 1988) and corresponding region of the linker scanning mutant $\Delta \mathrm{LS}-122 /-143$.CAT lacking the C/EBP-binding site. The C/EBP and the consensus AP-1 (Jun)-binding sites are underlined, and the BamHI linker insert is in boldface type. $(B)$ Nucleotide sequences between positions -130 and -10 of the SCD1 promoter (Ntambi et al. 1988). The C/EBP- and SCD1/BP- binding sites are underlined, and the deletion end points are indicated by vertical arrows.

pression of C/EBP message mimics that of the expression of several adipose-specific genes, that is, glycerol-3dehydrogenase (Birkenmeier et al. 1989), 422(aP2) protein (Fig. 4; Bernlohr et al. 1985), and SCD1 (Bernlohr et al. 1985). Thus, the temporal pattern of expression of the C/EBP, glycerol-3-phosphate dehydrogenase, $422(\mathrm{aP} 2)$, and SCD1 genes is appropriate for the involve-

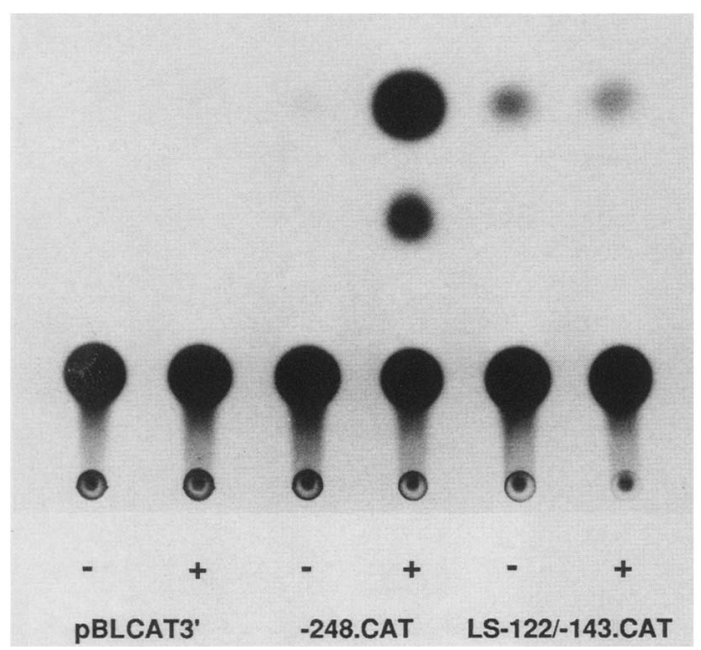

Figure 8. Trans-activation of the $422(\mathrm{aP} 2)$ promoter by C/EBP. Preconfluent 3T3-L1 cells were transfected with $20 \mu \mathrm{g}$ of the promoterless pBLCAT vector (pBLCAT3') or the $422(\mathrm{aP} 2)$ wt $\Delta-248$.CAT gene or the $422(\mathrm{aP2})$ mutant $\Delta \mathrm{LS}-122 /-$ 143.CAT gene, together with $20 \mu \mathrm{g}$ of pGEMblue carrier DNA $1-1$ or with $20 \mu \mathrm{g}$ of the C/EBP expression vector pMSV-C/EBPwt $(+1$. Cells were harvested, extracts prepared, and CAT enzyme assays performed $48 \mathrm{hr}$ after transfection (Gorman et al. 1982). ment of $\mathrm{C} / \mathrm{EBP}$ in activating the expression of these adipose-specific genes during preadipocyte differentiation. These findings, together with results showing that transfection of a C/EBP expression vector (pMSV-C) EBP-wt) into $3 \mathrm{~T} 3-\mathrm{L} 1$ preadipocytes trans-activates the promoters of the $422(\mathrm{aP2})$ and SCD1 genes, implicate $\mathrm{C} / \mathrm{EBP}$ in the differentiation-induced expression of adipose-specific genes in $3 \mathrm{~T} 3$ preadipocytes.

Friedman et al. (1989) report that C/EBP also activates the promoter of the serum albumin gene in cultured hepatoma cells. The fact that C/EBP trans-activates expression of both liver- and adipose-specific genes and is, itself, expressed primarily in these major fatty-acid-metabolizing tissues, suggests a global role for C/EBP in the regulation of lipid metabolism at the transcriptional level. It should be noted that both albumin and 422(aP2) protein bind and transport long-chain fatty acids, that is, albumin in the bloodstream and $422(\mathrm{aP} 2)$ protein within the adipocyte. Also noteworthy is the fact that the SCD1 gene is expressed both in adipose tissue and liver, which are the major sites of C/EBP expression.

In addition to the C/EBP-binding site, the promoter of the $422(\mathrm{aP} 2)$ gene contains another nuclear factor binding site (between nucleotides -124 and -107 ) that encompasses a consensus AP-1 (Jun)-binding sequence. Previous investigations have shown that this site interacts with a nucleoprotein complex containing Fos and AP-1 (Jun) (Distel et al. 1987; Franza et al. 1988; Rauscher et al. 1988). This segment of the $422(\mathrm{aP} 2)$ promoter contains overlapping negative and positive regulatory elements (Distel et al. 1987; Yang et al. 1989). Investigation of the effects of deletion mutations in this region of the $422(\mathrm{aP} 2)$ promoter indicates that the inhibitory effect of the negative regulatory element is lost 
Table 1. Trans-activation by C/EBP of wild-type and mutant 422(aP2) promoter-CAT and SCD1 promoter-CAT genes in 3T3-L1 preadipocytes

\begin{tabular}{llcl}
\hline & \multicolumn{2}{c}{$\begin{array}{c}\text { CAT activity } \\
\text { (pmoles/hr/l0-cm cell monolayer) }\end{array}$} \\
\cline { 2 - 4 } $\begin{array}{l}\text { Promoter-CAT } \\
\text { gene construct }\end{array}$ & none & pMSV-C/EBP-wt & $\begin{array}{c}\text { Fold } \\
\text { induction }\end{array}$ \\
\hline 422(aP2) & & & 0.97 \\
pBLCAT3' & 0.77 & 0.75 & 68.0 \\
$\Delta-248 . C A T$ & 0.78 & 53.0 & 0.93 \\
$\Delta$ LS - 122/ - 143.CAT & 3.1 & 2.9 & 3.7 \\
SCD1 & 0.12 & 0.44 & 21.0 \\
pBLCAT3 & 0.15 & 3.2 & 4.0 \\
$\Delta-93 . S C D 1 . C A T$ & 0.14 & 0.57 & \\
$\Delta-58 . S C D 1 . C A T$ & & & \\
\hline
\end{tabular}

Chimeric wild-type or mutant promoter-CAT genes were cotransfected with carrier (none) or with a C/EBP expression vector (pMSV-C/EBP-wt) into 3T3-Ll preadipocytes. After $48 \mathrm{hr}$, CAT assays were performed as described in Materials and methods. Each experiment was repeated three to five times, and the results of a typical experiment are shown. The range of activation by $\mathrm{C} / \mathrm{EBP}$ for these two promoters in all experiments was 15 - to $\sim 60$-fold.

during differentiation (Yang et al. 1989). Although the mechanism by which the inhibitory effect is lost is unknown, it most likely involves a differentiation-induced alteration of the interaction of a nuclear factor(s) in this region of the promoter.
The AP-1 (Jun) consensus sequence binding proteins, that is, the proto-oncogenes c-fos and c-jun, share amino acid sequence homology and the leucine zipper structural motif with C/EBP (Landschulz et al. 1988a). The leucine zipper of these transcription factors has been

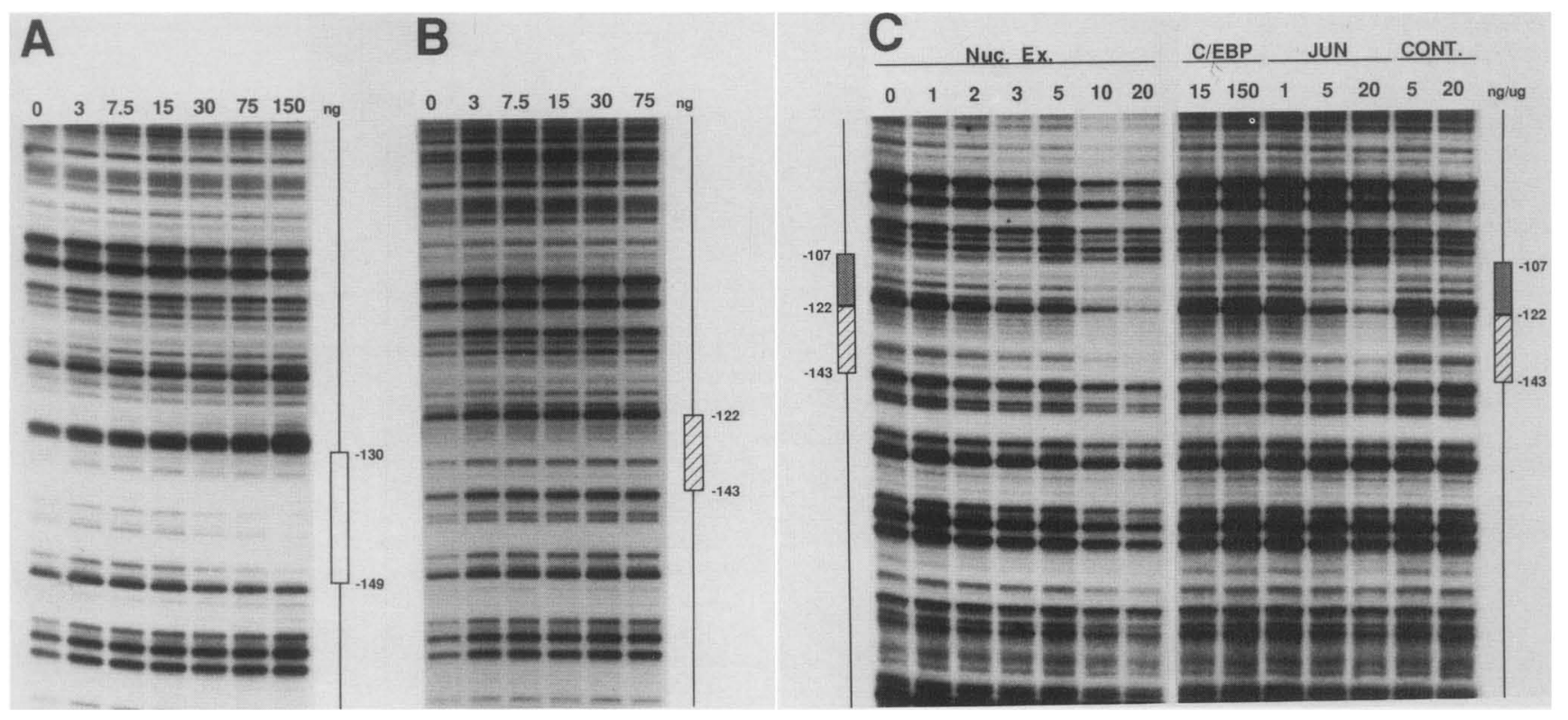

Figure 9. DNase I footprint analysis of $422(\mathrm{aP} 2) \Delta--248$.CAT and mutant $\Delta-\mathrm{LS}-122 /-143$.CAT chimeric genes. The NsiI-PstI fragment of the $422(\mathrm{aP} 2)$ promoter cloned into the pBLCAT3' expression vector $(A)$ and the linker-scanning mutant $\Delta L S-122 /-$ 143.CAT gene $(B)$ were incubated with increasing amounts $(3-150 \mathrm{ng})$ of purified recombinant C/EBP. $(A)$ DNase I protection of the $\Delta-248$.CAT construct; the open-boxed region (nucleotides -149 to -130 ) indicates the C/EBP-binding site. (B) DNase I protection of the $\Delta-122 /-143$.CAT linker scanning mutant gene; the hatched box indicates the location of the BamHI linker sequence, inserted into the 422(aP2) 248-bp fragment, which deletes the C/EBP-binding site but leaves the AP-1 (Jun) site intact (see Fig. 7). The nucleotides shown $(-122,-143)$ indicate the end points of the $422(\mathrm{aP} 2)$ promoter sequences to which the BamHI linker was added (hatched box). $(C)$ Increasing amounts (1-20 $\mu$ g) of nuclear extract from differentiated 3T3-L1 (day 4) cells, purified recombinant C/EBP (15 and $150 \mathrm{ng}$ ), bacterially expressed recombinant c-jun $(1-20 \mu \mathrm{g})$ or control c-jun bacterial extract (5 and $20 \mu \mathrm{g}$ ), were incubated with the $\Delta \mathrm{LS}-122$ / - 143.CAT linker-scanning mutant. The hatched box (nucleotides -107 to -122 ) denotes the 422 promoter sequences that contain the intact AP-1 (Jun) consensus sequence, and the end points on the hatched box (nucleotides - 122, - 143) indicate the end points of the $422(\mathrm{aP} 2)$ promoter sequence to which the BamHI linker has been added. (0) Control reaction without nuclear extract or recombinant proteins. 
shown to play a role both in intact cells and in vitro by facilitating the formation of stable complexes that lead to a sequence-specific interaction between leucine zipper-containing proteins and their promoter-binding sites (Gentz et al. 1989; Turner and Tijan 1989). The proximity of the C/EBP- and AP-1-binding sites in the $422(\mathrm{aP} 2)$ promoter raises the possibility that $\mathrm{C} / \mathrm{EBP}$, bound to its specific site, and a protein, for example, Jun, bound at the AP-1 site, may interact and thereby affect expression. Presently, we are investigating the possible interactions of the differentiation-specific factor C/EBP with c-Jun and c-Fos and their role in the activation of the 422(aP2) gene.

Comparison of the nucleotide sequences of the C/EBP-binding sites within the promoters of the $422(\mathrm{aP} 2)$ and SCD1 genes reveals that they contain the same 5-bp GAAAT sequence. This sequence is related distantly to the CCAAT box to which C/EBP binds (Graves et al. 1986) and has limited homology to the $\mathrm{C} / \mathrm{EBP}$-binding sites of other genes and to the consensus sequence compiled from an analysis of these sites by Ryden and Beemon (1989), $\mathrm{T}^{\mathrm{T}}{ }_{\mathrm{G}} \mathrm{NNG}^{\mathrm{C}} \mathrm{TAA}^{\mathrm{T}}{ }_{\mathrm{G}}$, but has not been shown definitively to be the sequence necessary for $\mathrm{C} / \mathrm{EBP}$ binding to the $422(\mathrm{aP} 2$ ) and SCDI promoters. Preliminary analysis of the promoters of several other genes that are expressed differentially when $3 \mathrm{~T} 3-\mathrm{L} 1$ preadipocytes differentiate reveals that these promoters also contain a putative C/EBP binding site (K. Kaestner and M.D. Lane, unpubl.). These promoters are being analyzed presently for C/EBP-binding activity and their capacity for trans-activation by $\mathrm{C} / \mathrm{EBP}$.

The level of endogenous $422(\mathrm{aP} 2)$ and SCD1 mRNA is increased 5- to 10-fold, and the DNase I footprinting by nuclear extracts of the C/EBP-binding sites in these genes is enhanced by treatment of 3T3-Ll preadipocytes with cAMP (V.W. Yang, J.M. Ntambi, and M.D. Lane, unpubl.). Although expression of C/EBP is increased greatly during differentiation of 3T3-L1 cells, a low level of this nuclear factor can be detected in nuclear extracts of 3T3-L1 preadipocytes by gel retardation assays using segments of the $422(\mathrm{aP2})$ or SCD1 promoters (results not shown). Likewise, low levels of C/EBP mRNA are detected in undifferentiated 3T3-L1 preadipocytes (Fig. 5). This low cellular level of C/EBP may be responsible for the activation by cAMP of the $422(\mathrm{aP} 2)$ and SCD1 promoters observed in 3T3-Ll preadipocytes (Ntambi et al. 1988; Yang et al. 1989). The mechanism by which the $422(\mathrm{aP} 2)$ and SCD1 promoters are activated by cAMP may be analogous to that for CAMP response element nuclear binding protein (CREB), where cAMP activates transcription of the somatostatin gene by causing the phosphorylation of the CREB protein (Yamamoto et al. 1988). The activating effect of CAMP on the expression of a $422(\mathrm{aP} 2)$ promoter-reporter gene, transfected transiently into 3T3-L1 preadipocytes, is lost when the C/EBP binding site is deleted (Yang et al. 1989). Preliminary results in our laboratory (R.J. Christy and V.W. Yang, unpubl.) indicate that recombinant C/EBP can be phosphorylated in vitro by the catalytic subunit of protein kinase A. Furthermore, endogenous C/EBP from in- tact 3T3-L1 preadipocytes was phosphorylated when the cells were treated with cAMP. The effect of the phosphorylation of C/EBP on its binding to and activation of the $422(\mathrm{aP} 2)$ promoter are under investigation.

\section{Materials and methods}

Cell culture

The 3T3-L1 preadipocytes were maintained and differentiated as described previously (Reed and Lane 1980; Student et al. 1980). Briefly, differentiation was induced by treating 2-day postconfluent cells (designated day 0 ) with $10 \%$ fetal bovine serum $(\mathrm{FBS}), 1.7 \mu \mathrm{M}$ insulin, $1 \mu \mathrm{M}$ dexamethasone, and $0.5 \mathrm{~mm}$ 3-isobutyl-1-methylxanthine in Delbecco's modified Eagle's medium (DMEM). After $48 \mathrm{hr}$ the medium was replaced with DMEM supplemented only with $1.7 \mu \mathrm{M}$ insulin and $10 \%$ FBS. By day 3 , cells had begun to accumulate cytoplasmic triacylglycerol. Preadipocyte control cells were maintained in DMEM containing $10 \%$ calf serum.

\section{Isolation and analysis of RNA}

Total cellular RNA was isolated from undifferentiated and differentiated $3 \mathrm{~T} 3-\mathrm{Ll}$ cells, using the guanidine isothiocyanate method (Chirgwin et al. 1979). Fifteen micrograms of each RNA sample was denatured and analyzed on a $1.25 \%$ agarose gel containing $2.2 \mathrm{M}$ formaldehyde. The gel was transferred to Hybond-N (Amersham), UV-shadowed to locate the $28 \mathrm{~S}$ and $18 \mathrm{~S}$ rRNAs, and hybridized to a DNA radiolabeled probe, as described previously (Ntambi et al. 1988).

\section{Radiolabeled probes}

DNA probes for Northern analysis were labeled by the random hexamer priming method (Feinberg and Vogelstein 1983). The 422 (aP2) hybridization probe was the full-length cDNA (Bernlohr et al. 1984). The C/EBP hybridization probe was isolated from a cDNA library prepared using poly $(\mathrm{A})^{+}$RNA from day-5 3T3-Ll adipocytes (Ntambi et al. 1988). The library was screened using a 415-bp SmaI fragment from the rat C/EBP cDNA corresponding to nucleotides 452-867 (Johnson et al. 19871. A cDNA was isolated from the 3T3-L1 library, which corresponds to nucleotides 490-2651 of the corresponding rat C/EBP sequence (Johnson et al. 1987). A 1400-bp fragment of the 3T3-LI C/EBP cDNA, which contains both coding and noncoding sequences, was used as a hybridization probe for Northern analysis.

The 5'-end-labeled DNA fragments were generated by digesting plasmid DNA with appropriate restriction enzymes, treating with calf intestinal phosphatase (Boehringer-Mannheiml, and $5^{\prime}$ end-labeling with T4 polynucleotide kinase and ( $y$-32 $\mathrm{p} \mid$ ATP $(6000 \mathrm{Ci} / \mathrm{mmole}$, New England Nuclear) (Maniatis et al. 1982). The 5'-end-labeled DNAs were digested with a second restriction enzyme, and fragments were purified on a $6 \%$ acrylamide gel in $1 \times$ TBE $[89 \mathrm{~mm}$ Tris, $89 \mathrm{~mm}$ borate, 2.5 mM EDTA $[\mathrm{pH} 8.31]$ The radioactive DNA fragments were visualized by autoradiography, excised, electroeluted, and purified over NACS-52 Prepac columns (BRL).

\section{Preparation of nuclear extracts}

Nuclear extracts from $3 \mathrm{~T} 3-\mathrm{Ll}$ cells were prepared using a modification of the procedure of Ohlsson and Edlund (1986). At various times after initiating differentiation, cells were washed twice with phosphate-buffered saline (PBS) and scraped from 
the dish with a rubber policeman. All subsequent steps were carried out at $4^{\circ} \mathrm{C}$. The cells were pelleted at $2000 \mathrm{~g}$ for $10 \mathrm{~min}$ and resuspended in five packed cell volumes of buffer $\mathrm{A}$, which contained $10 \mathrm{~mm}$ HEPES ( $\mathrm{pH} 7.8$ at $4^{\circ} \mathrm{C}$ ), $15 \mathrm{mM} \mathrm{KCl}, 2 \mathrm{mM}$ $\mathrm{MgCl}_{2}, 0.1 \mathrm{mM}$ EDTA, $1 \mathrm{mM}$ DTT, and $1 \mathrm{~mm}$ phenylmethylsulfonyl flouride (PMSF). Then the cells were pelleted at $2000 \mathrm{~g}$ for $10 \mathrm{~min}$ and resuspended in two original packed cell volumes of buffer A. The cells were lysed using a Kontes all-glass Dounce homogenizer (6-12 strokes with type-B pestlel, and isotonicity was restored by adding one-tenth volume buffer $B$ which contained $50 \mathrm{mM}$ HEPES (pH 7.8), 1 M KCl, $30 \mathrm{~mm}$ $\mathrm{MgCl}_{2}, 0.1 \mathrm{mM}$ EDTA, $1 \mathrm{~mm}$ DTT, and $1 \mathrm{~mm}$ PMSF. The cell homogenate was centrifuged at $7500 \mathrm{~g}$ for $10 \mathrm{~min}$ after which the cell pellet was washed with isotonic buffer $A$ and recentrifuged. The crude nuclear pellet was resuspended in $1-2 \mathrm{ml}$ of isotonic buffer $\mathrm{A}$, transferred to a Beckman type 70.1 ultracentrifuge tube, and $4 \mathrm{M}\left(\mathrm{NH}_{4}\right)_{2} \mathrm{SO}_{4}$ was added to a final concentration of $0.3 \mathrm{M}$. The crude nuclei were lysed by gentle rocking for $30-45 \mathrm{~min}$ and the debris sedimented by centrifugation at $100,000 \mathrm{~g}$ for $1 \mathrm{hr}$. The supernatant was retained, and solid $\left(\mathrm{NH}_{4}\right)_{2} \mathrm{SO}_{4}$ was added to a final concentration of $45 \%$. After 30 $\mathrm{min}$, the precipitate was collected by centrifugation at $100,000 \mathrm{~g}$ for $15 \mathrm{~min}$ and resuspended in buffer $C$ containing $25 \mathrm{~mm}$ HEPES, $50 \mathrm{~mm} \mathrm{KCl}, 0.1 \mathrm{mM}$ EDTA, $1 \mathrm{mM}$ DTT, $1 \mathrm{mM}$ PMSF, and $20 \%$ glycerol. The extracts were dialyzed in 300 volumes of buffer $C$ for $4-6 \mathrm{hr}$ with three buffer changes. The insoluble precipitate was cleared by centrifugation at $12,000 \mathrm{~g}$ for $10 \mathrm{~min}$ and the supernatant was aliquoted, frozen in liquid nitrogen, and stored at $-70^{\circ} \mathrm{C}$. Protein concentrations, normally between 1-3 mg/ml, were determined by the method of Bradford (1976).

Purified C/EBP protein was prepared as described previously (Landschulz et al. 1989).

The c-iun expression vector was a gift from Y. Nakabeppu and $D$. Nathans. The vector contains the entire coding region of c-jun under the control of the Lac promoter (Y. Nakabeppu, pers. comm.). For expression, either the vector with the c-iun insert or without an insert was grown and induced, and lysates were prepared as described previously (Bohmann et al. 1987). Crude bacterial lysates were used for DNase I protection assays.

\section{DNase I protection and gel retardation assays}

The DNase I footprinting procedure has been described previously (Graves et al. 1986). Each reaction contained $\sim 1-2 \mathrm{ng}$ of 5 '-end-labeled DNA, which was resolved on a $6 \%$ polyacrylamide/8 $\mathrm{M}$ urea sequencing gel. DNase I cleavage sites that were protected from digestion were identified using chemical cleavage sequencing reactions (Maxam and Gilbert 1980).

Gel retardation assays (Fried and Crothers 1981; Garner and Revzin 1981) were carried out in $25 \mu l$ containing $25 \mathrm{~mm}$ HEPES (pH 7.8), $50 \mathrm{~mm} \mathrm{KCl}, 0.1 \mathrm{~mm}$ EDTA, $1 \mathrm{~mm}$ DTT, $10 \%$ glycerol, and $2 \mu \mathrm{g}$ poly[d(I-C)] (Pharmacia). End-labeled DNA $(0.5-1 \mathrm{ng})$ was incubated with $2.5 \mu \mathrm{g}$ of nuclear extract for 15 min at $25^{\circ} \mathrm{C}$ after which $1 \mu l$ of $0.2 \%$ bromphenol blue/xylene cyanol was added and samples were loaded immediately on a $4.5 \%$ acrylamide gel $(39: 1$ acrylamide/bis-acrylamide) in $0.5 \times$ TBE.

\section{DNA fragments and synthetic DNA oligonucleotides}

DNA fragments used in DNase I protection (footprinting) assays included a 248-bp NsiI-Pst I fragment of the 422(aP2) gene (Cook et al. 1988) and a 120-bp BstNI fragment of the SCD1 gene, corresponding to nucleotides -136 to -14 (Ntambi et al. 1988). The 422(aP2) fragment was subcloned into the pUC18 HincII-PstI site and was digested with EcoRI (coding strand) or HindIII (noncoding strand) for 5' end-labeling. The 120-bp SCD1 fragment was subcloned into the HincII site of pGEMblue (Promega Biotec) and digested with HindIII (coding strand) or EcoRI (noncoding strand) for 5' end-labeling.

The linker-scanning mutant $\Delta \mathrm{LS}-122 /-141$. CAT and the $\Delta-248 . C A T$, which are cloned into pBLCAT3' vector isee below), were digested with $\mathrm{XbaI}$ (coding strand) for $5^{\prime}$ end-labeling.

Synthetic oligonucleotides for the gel retardation assays were synthesized on an Applied Biosystems DNA synthesizer and purified by high-performance liquid chromatography (HPLC). The oligonucleotides were constructed to create overhanging BamHI, BgIII, or XbaI restriction sites. The sequences of the oligonucleotides for the 422(aP2) gene are CTAGAAACAT. GACTCAGAGGAAAACATACAGG $(-127$ to -100$)$ and GATCCAAAGTTGAGAAATTTCTATTAAAAA $1-150$ to -125 ), and for the SCD1 gene are GATCCAGGGGGCTGAGGAAATAG $(-80$ to -59$)$ and GATCCTCTGCGCTCTTTACCCTTTGCTGGCA $(-116$ to -90$)$. The oligonucleotides were annealed and suspended in buffer $\mathrm{C}$ for gel retardation experiments.

\section{Construction and transfection of chimeric promoter-CAT genes}

The 248-bp NsiI-PstI fragment of the $422(\mathrm{aP} 2)$ gene was used to make $5^{\prime}$ - and $3^{\prime}$-deletion mutants, as described previously (Yang et al. 1989). Using the appropriate $5^{\prime}$ deletion $\left(5^{\prime} \Delta-122 . C A T\right)$ and $3^{\prime}$ deletion $\left(3^{\prime} \Delta-143\right.$.CAT $)$, the mutants were digested with $X b a I$ and $B a m H I$ to generate the linker scanning mutant $\Delta \mathrm{LS}-122 /-143$.CAT (V.W. Yang et al., in prep.). This mutant lacks the entire C/EBP-binding site and has inserted in its place a 10-bp BamHI linker sequence. The 5' deletion mutants of the SCDl promoter region were obtained by digesting the 363-bp AccI-Aval fragment (Ntambi et al. 1988) with Bal31 and cloning into the pBLCAT3 vector (Luckow and Schütz 1987; Ntambi et al., in prep.).

These chimeric CAT constructs were transfected into $30 \%$ confluent, proliferating 3T3-Ll preadipocytes by calcium/phosphate coprecipitation (Graham and van der Eb 1973). Twenty micrograms of $\mathrm{CsCl}$ gradient-purified chimeric wild-type/ or mutant promoter/CAT DNA and $20 \mu \mathrm{g}$ of either pMSV-C/EBPwt expression vector DNA (Friedman et al. 1989) or pGEMblue (Promega Biotec) carrier DNA was coprecipitated. After 8-12 $\mathrm{hr}$, the cells were shocked with $10 \%$ dimethylsulfoxide and washed twice with PBS, after which fresh DMEM with $10 \%$ calf serum was added. After an additional $36 \mathrm{hr}$, cell extracts were prepared and CAT activity was determined by thin layer chromatography (Gorman et al. 1982) or by the scintillation fluor diffusion method (Neumann et al. 1987).

\section{Acknowledgments}

We thank Steve McKnight for his interest, help, and comments. We also thank Klaus Kaestner, Eric Sibley, and Michael Zierler for helpful discussions and comments, and Natalie Tumminia for excellent assistance in the preparation of this manuscript. This work was supported by a research grant from the National Institutes of Health (NIH) (NIDDK-38418). R.J.C. and V.W.Y. were supported by National Research Service Awards (5F32NIDDK081903, 5F32-NIDDK08088), and A.D.F. by a Physician Scientist Award from the NIH. W.H.L. is a Medical Scientist Scholar of the Life and Health Insurance Medical Research Fund. 


\section{References}

Bernlohr, D.A., M.A. Bolanowski, T.J. Kelly, and M.D Lane. 1985. Evidence for an increase in transcription of specific mRNAs during differentiation of 3T3-L1 adipocytes. I. Biol. Chem. 260: 5563-5567.

Bernlohr, D.A., C.W. Angus, M.D Lane, M.A. Bolanowski, and T.J. Kelly. 1984. Expression of specific mRNA during adipose differentiation: Identification of an mRNA encoding a homologue of myelin P2 protein. Proc. Nat1. Acad. Sci. 81: 5468--5472.

Birkenmeier, E.H., B. Gwynn, S. Howard, J. Jerry, J.I. Gordon, W.H. Landschulz, and S.L. McKnight. 1989. Tissue-specific expression and developmental and genetic mapping of the gene encoding C/EBP. Genes Dev. 3: 1146-1156.

Bohmann, D., T.J. Bos, T. Nishimura, P.K. Vogt, and R. Tiian. 1987. Human proto-oncogene c-jun encodes a protein with antigenic and enhancer binding properties of transcription factor AP-1. Science 238: 1386-1392.

Bradford, M.M. 1976. A rapid and sensitive method for the quantitation of microgram quantities of protein utilizing the principle of protein-dye binding. Anal. Biochem. 72: 248258.

Chapman, A.B., D.M. Knight, B.S. Dieckman, and G.M. Ringold. 1984. Analysis of gene expression during differentiation of adipogenic cells in culture and hormonal control of the developmental program. J. Biol. Chem. 259: 1554815555.

Chirgwin, J.M., A.E. Przybyla, R.J. MacDonald, and W.J. Rutter. 1979. Isolation of biologically active ribonucleic acid from sources enriched in ribonuclease. Biochemistry 24: 52945299.

Cohen, D.R., C.P. Ferreira, R. Gentz, B.R. Franza Jr., and T. Curran. 1989. The product of a Fos-related gene, fra-1, binds cooperatively to the AP-1 site with Jun: Transcription factor AP-1 is comprised of multiple protein complexes. Genes Dev. 3: 173-184.

Coleman, R.A., B.C. Reed, J.C. Mackall, A.K. Student, M.D. Lane, and R.M. Bell. 1978. Selective changes in microsomal enzymes of triacylglycerol phosphotidylcholine, and phosphotidylethanolamine biosynthesis during differentiation. $J$. Biol. Chem. 253: 7256-7261.

Cook, K.S., C.R. Hunt, and B.M. Spiegelman. 1985. Developmentally regulated mRNA in 3T3-adipocytes: Analysis of transcriptional control. $/$. Cell. Biol. 100: 514-520.

Cook, J.S., J.J. Lucas, E. Sibley, M.A. Bolanowski, R.J. Christy, T.J. Kelly, and M.D. Lane. 1988. Expression of the differentiation-induced gene for fatty-acid binding protein is activated by glucocorticoid and cAMP. Proc. Natl. Acad. Sci. 85: 2949-2953.

Distel, R.J., J.H.-S. Ro, B.S. Rasen, D.L. Groves, and B.M. Spiegelman. 1987. Nucleoprotein complexes that regulate gene expression in adipocyte differentiation: Direct participation of c-fos. Cell 49: 835-844.

Enoch, H.G., A. Catgalä, and P. Strittmatter. 1976. Mechanism of rat liver microsomal stearoyl-CoA desaturase. I. Biol. Chem. 251: 5095-5103.

Feinberg, A.P. and B. Vogelstein. 1983. High specific activity labeling of DNA restriction endonuclease fragments. Anal. Biochem. 132: 6-13.

Franza Jr., B.R., F.J. Rauscher III, S.F. Josephs, and T. Curran. 1988. The Fos complex and Fos-related antigens recognize sequence elements that contain AP-1 binding sites. Science 239: $1150-1153$.

Fried, M. and D.M. Crothers. 1981. Equilibria and kinetics of Lac repressor operator interactions by polyacrylamide gel electrophoresis. Nucleic Acids Res. 9: 6505-6525.
Friedman, A.D., W.H. Landschulz, and S.L. McKnight. 1989. $\mathrm{C} / \mathrm{EBP}$ activates the promoter of the serum albumin gene in cultured hepatoma cells. Genes Dev. 3: 1314-1322.

Garner, M.M. and A. Revzin. 1981. A gel electrophoresis method for quantifying the binding to specific DNA regions: application to components of E. coli lactose operon regulatory system. Nucleic Acids Res. 9: 3047-3060.

Gentz, R., F.J. Rauscher III, C. Abate, and T. Curran. 1989. Parallel association of Fos and Jun leucine zippers juxtaposes DNA binding domains. Science 243: 1695-1699.

Gorman, C.M., L.E. Moffat, and B.H. Howard. 1982. Recombinant genomes which express chloramphenicol acetyltransferase in mammalian cells. Mol. Cell. Biol. 2: 1044-1051.

Graham, F.L. and A.J. van der Eb. 1973. A new technique for the assay of infectivity of human adenovirus 5 DNA. Virology 52: $456-457$.

Graves, B.J., P.F. Johnson, and S.L. McKnight. 1986. Homologous recognition of a promoter domain common to the MSV LTR and the HSV tk gene. Cell 44: 565-576.

Green, H. and O. Kehinde. 1974. Sublines of mouse 3T3 cells that accumulate lipid. Cell 1: 113-116.

1975. An established preadipose cell line and its differentiation in culture. II. Factors affecting the adipose conversion. Cell 5: 19-27

- 1976. Spontaneous heritable changes leading to increased adipose conversion in 3T3 cells. Cell7: 105-113.

Hunt, C.R., J.H.-S. Ro, D.E. Dobson, H.Y. Min, and B.M. Spiegelman. 1986. Adipocyte P2: Developmental expression and homology of 5 -flanking sequences among fat cell-specific genes. Proc. Natl. Acad. Sci. 83: 3786-3790.

Johnson, P.F., W.H. Landschulz, B.J. Graves, and S.L. McKnight. 1987. Identification of a rat liver nuclear protein that binds to the enhancer core element of three animal viruses. Genes Dev.1: 133-146.

Kaestner, K.H., J.M. Ntambi, T.J. Kelly, Jr., and M.D. Lane. 1989a. Differentiation-induced gene expression in 3T3-L1 preadipocytes: A second differentially-expressed gene encoding stearoyl-CoA desaturase. J. Biol. Chem. 264 (in press\}.

Kaestner, K.H., R.J. Christy, J.C. McLenithan, L.T. Braiterman, preadipocytes. Cornelius, P.H. Pekala, and M.D. Lane $1989 \mathrm{~b}$. Sequence, tissue distribution and differential expression of mRNA for a putative insulin-responsive glucose transporter in mouse 3T3-Ll adipocytes. Proc. Natl. Acad. Sci. 86: 3150-3154.

Landschulz, W.H., P.F. Johnson, and S.L. McKnight. 1988a. The Leucine Zipper: A hypothetical structure common to a new class of DNA binding proteins. Science 240: 1759-1764.

. 1989. The DNA binding domain of the rat liver nuclear protein C/EBP is bipartite. Science 243: 1681-1688.

Landschulz, W.H., P.F. Johnson, E.Y. Adashi, B.J. Graves, and S.L. McKnight. 1988b. Isolation of a recombinant copy of the gene encoding C/EBP. Genes Dev. 2: 786-800.

Luckow, B. and G. Schütz. 1987. CAT constructions with multiple unique restriction sites for the functional analysis of eukaryotic promoters and regulatory elements. Nucleic Acids Res. 15: 5490.

Mackall, J.C., A.K. Student, S.E. Polakis, and M.D. Lane. 1976. Induction of lipogenesis during differentiation in a 'preadipocyte' cell line. J. Biol. Chem. 251: 6462-6464.

Maniatis, T., E.F. Fritsch, and I. Sambrook. 1982. Molecular cloning: A laboratory manual. Cold Spring Harbor Laboratory, Cold Spring Harbor, New York.

Matarese, V. and D.A. Bernlohr. 1988. Purification of murine adipocyte lipid-binding protein. $J$. Biol. Chem. 263: 1454414551. 
Maxam, A. and W. Gilbert. 1980. Sequencing end-labeled DNA with base specific chemical cleavages. Methods Enzymol. 65: 499-560.

Nakabeppu, Y., K. Ryder, and D. Nathans. 1988. DNA binding activities of three murine Jun proteins: Stimulation by Fos. Cell 55: 907-915.

Neumann, J.R., C.A. Morency, and K.O. Russian. 1987. A novel assay for chloramphenicol acetyltransferase gene expression. Biotechnology 5: 444-447.

Ntambi, J.M., S.A. Buhrow, K.H. Kaestner, R.J. Christy, E. Sibley, T.J. Kelly, and M.D. Lane. 1988. Differentiation-induced gene expression in 3T3-L1 preadipocytes. $/$. Biol. Chem. 263: 17291-17300.

Ohlsson, H. and T. Edlund. 1986. Sequence-specific interactions of nuclear factors with the insulin gene enhancer. Cell 45: $35-44$.

Phillips, M., P. Djian, and H. Green. 1986. The nucleotide sequence of three genes participating in the adipose differentiation of 3T3 cells. J. Biol. Chem. 261: 10821-10827.

Rauscher III, F.J., L.C. Sambucetti, T. Curran, R.J. Distel, and B.M. Spiegelman. 1988. Common DNA binding site for Fos protein complexes and transcription factor AP-1. Cell 52: $471-480$.

Reed, B.C. and M.D. Lane. 1980. Insulin receptor synthesis and turnover in differentiating 3T3-L1 preadipocytes. Proc. Natl. Acad. Sci. 77: 285-289.

Rosen, O.M., C.J. Smith, A. Hirsch, E. Lai, and C.S. Rubin. 1979. Recent studies of the 3T3-L1 adipocyte-like cell line. Recent Prog. Horm. Res. 35: 477-499.

Ryden, T.A., K. Beemon. 1989. Avian retroviral long terminal repeats bind CCAAT/Enhancer-binding protein. Mol. Cell. Biol. 9: 1155-1164.

Spiegelman, B.M., M. Frank, and M. Green. 1983. Molecular cloning of mRNA from $3 \mathrm{~T} 3$ adipocytes. 1. Biol. Chem. 258: $10083-10098$.

Student, A.K., R.Y. Hsu, and M.D. Lane. 1980. Induction of fatty acid synthetase synthesis in differentiating 3T3-L1 preadipocytes. J. Biol. Chem. 255: 4745-4750.

Turner, R. and R. Tjian. 1989. Leucine repeats and an adjacent DNA binding domain mediate the formation of functional cfos-cjun heterodimers. Science 243: 1689-1694.

Wingender, E. 1988. Compilation of transcription regulatory proteins. Nucleic Acids Res. 16: 1879-1902.

Yamamoto, K.K., G.A. Gonzalez, W.H. Biggs III, and M.R. Montminy. 1988. Phosphorylation-induced binding and transcriptional efficacy of nuclear factor CREB. Nature 334: 494-498.

Yang, V.W., R.J. Christy, J.S. Cook, T.J. Kelly, and M.D. Lane. 1989. Mechanism of regulation of the $422(\mathrm{aP} 2)$ gene by cAMP during preadipocyte differentiation. Proc. Natl. Acad. Sci. 86: $3629-3633$. 


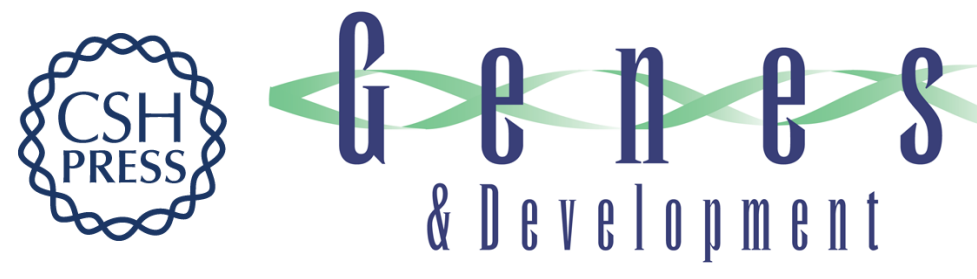

\section{Differentiation-induced gene expression in 3T3-L1 preadipocytes: CCAAT/enhancer binding protein interacts with and activates the promoters of two adipocyte-specific genes.}

R J Christy, V W Yang, J M Ntambi, et al.

Genes Dev. 1989, 3:

Access the most recent version at doi:10.1101/gad.3.9.1323

References This article cites 50 articles, 30 of which can be accessed free at: http://genesdev.cshlp.org/content/3/9/1323.full.html\#ref-list-1

License

Email Alerting Service

Receive free email alerts when new articles cite this article - sign up in the box at the top right corner of the article or click here.

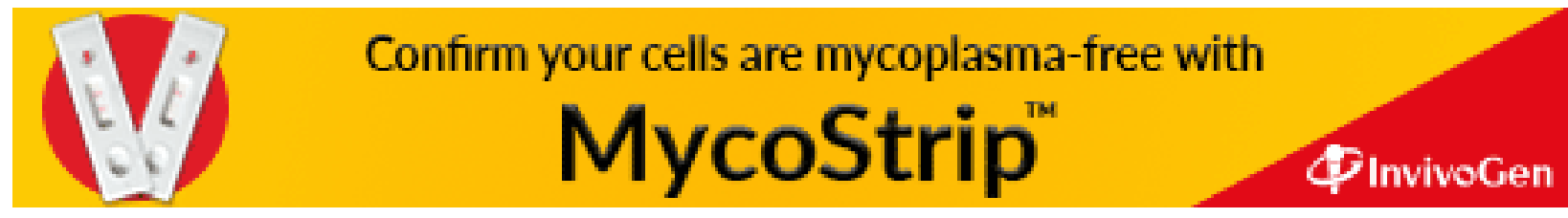

